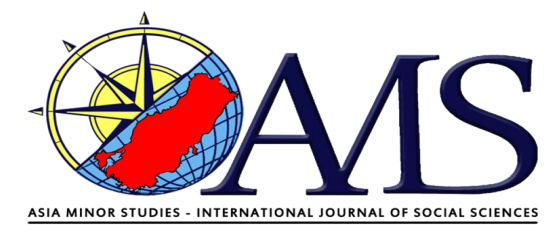

Cilt: 4 Sayı: 7 Ocak 2016 / Volume: 4 Issue: 7 January 2016

\title{
CIRCASSIAN REFUGEES: FUTURE RESIDENTS OF RUMELIA
}

\section{Çerkes Mülteciler: Rumeli’nin Müstakbel Sakinleri}

Yakup AHBAB*

\begin{abstract}
19 th age was a tragic period for the Ottoman State. The wars and result of them in this age were the main causes of the catastrophe above. The immigration was the most important result of this demolition. Because, the housing issues caused by immigration from the Caucasus and to direct them into Balkans. For immigrants territory was provided to settle in and they were supported to build their houses. Having been provided with agriculture tools and seeds they were give a fillip to take part in manufacture. In this study Caucasus arefugees in the Balkans considering to official Ottoman documents and article debated this topic in detail.
\end{abstract}

Keyword: Ottoman, Balkans, Rumelia, Circassian, Refugees

ÖZ

19. yüzyılda Rusya ile yapılan savaşlar nedeniyle bu yüzyıl Osmanla Devleti açısından tam bir faciadır. Bu dönemde özellikle Kafkasya'dan Rumeli topraklarına da göçler yapılmıştır. Devletin gerek iç gerekse de diş nedenlerden ötürü yaşadığı ekonomik sıkıntılar nedeniyle Rumeli’ye göç etmiş olan Çerkes sığınmacılarla pek fazla ilgilenememiştir. Dolayısıyla muhacirlerin iskanları esnasında istenmedik birçok sorunla karşılaşılmıştır. Yaşanan tüm olumsuzluklara rağmen Osmanlı Devleti kendine sığınan Çerkes göçmenleri Rumeli'de iskan etmiştir. Devlet bu göçmenlere, kalacak yer, tarım yapmaları ve geçimlerini temin etmeleri için araziler tahsis etmiştir. Sonuç olarak, 19. yüzyılın ikinci yarısında yaşanan bu göçler nedeniyle yüzbinlerce Çerkez vatanlarını terk etmek zorunda kalmış, bilmediği diyarlara göç etmiştir.

Anahtar Kelimeler: Osmanlı, Balkanlar, Rumeli, Çerkes, Mülteci

* PhD, yakupahbab@ hotmail.com

Makalenin Geliş ve Kabul Tarihi.: 17.06.2015-17.12.2015 
Circassian Refugees: Future Residents of Rumelia / Yakup AHBAB

\section{1) Migration}

The first migration from borders of Russia to the Ottoman Empire began with the occupation of the Crimea by the Russians in 1783. Later migration of Crimean Tatars increased steadily by the treaties of Yaş in 1792 and then Paris were signed has in 1856. After Crimea War, the spread of Russian to the Balkans and Anatolia was stopped for a while. Thus this state began to turn to Asia because of the interception of westward front of Russia's activity. The tranquility and peace of Muslims where they live in outside the political boundaries of the Ottoman Empire like Crimea, the Caucasus and Turkestan began to deteriorate. The number of migrants including the Crimeans, Dagestanis and Nogay between years 1860-1862 was approximately 230.000 . 4000 Circassian family migrated from long lands in the west of Cuba to Anatolia without resistance during 1860. Despite this, there were Circassian tribes who did not leave. Military operations were made against them in 1862. Although the Ottoman Empire came out victorious from the war, Russia made these people descend to plain by pressure or immigrate to the Ottoman Empire after war ${ }^{1}$.

Ongoing struggle of Circassians against the Russian invasion in the Caucasus since 1829 was weakened by arrest of Sheikh Shamil in December 5, $1859^{2}$. Although the summer of 1862 passed with quite bloody conflicts, the resistance was battered and struggle was attempted in small groups. Therefore, the Muslim community of Caucasus was convicted to choose the options of changing places within the country or migration to the Ottoman Empire ${ }^{3}$. While not accepting these options immediately, this weak struggle lasted until 1863 and resulted in May of 1864. Hereafter, the Russian czar gave Muslim Caucasian tribes a month respite for leaving the country ${ }^{4}$. Ottoman Empire sought assurances from immigrated refugees not to return or from Russia to claim any rights on migrated people. Thereupon Russia reported Ottoman Empire that they had received a document from the refugees regarding that they will not turn back after the migration, so that Ottoman Empire allowed those who want to migrate. Otherwise the immigrants

\footnotetext{
${ }^{1}$ Nedim İpek, Rumeli'den Anadolu'ya Türk Göcleri, TTK, Ankara 1994, s. 3.

2 John F.Baddeley, Rusların Kafkasya 'yı İstilası ve Seyh Şamil, (Çev. Sedat Özden), Kayıhan Yayınları, İstanbul 1989, s.449.

${ }^{3}$ The Russians had invaded Cherkezhistan for important military and strategic reasons like security and defense of Caucasus, freedom in circulation and trade in the Black Sea, the need to a secure rail link between Iran by Black Sea and Caspian Sea: Ömer Karataş, "19. Yüzyılda Balkanlarda Kafkas Muhacirlerinin İskanı', Türk Dünyası İncelemeleri Dergisi, XII/2 (Kış 2012), S. 355-388; A. Fonvill, Çerkesya Bağımsızlık Savaşı (1863-1864), (Çev. Murat Papsu), Nart Yayıncılık, İstanbul 1996, s.73; Süleyman Erkan, Kırım ve Kafkasya Göçleri (1878-1908), KTÜ Yayını, Trabzon 1996 s.25; Ferhat Berber, "Kırımlı ve Kafkasyalı Muhacirlerin Manisa Kazasında İskânı (1860-1876) ”, Sosyal Bilimler Dergisi, Cilt:11, Say1:3, Aralık 2013 Manisa Özel Sayısı, s. 169-192.

${ }^{4}$ Sedat Kanat, Osmanlı Devleti'ne Yapılan 1864 Kafkas Göçü, Atatürk Üniversitesi Sosyal Bilimler Enstitüsü, Yüksek Lisans Tezi, Erzurum 2011, s. 33.
} 
Circassian Refugees: Future Residents of Rumelia / Yakup AHBAB

were brought of the condition to be Ottoman citizens. Russia suggested as a condition that immigrants was not placed close to the Russian border 5 .

Forced migration gained great momentum during the Crimean war in 18561857; in 1860-1862 after the delivery of Imam Shamil to the Russian State in 1859; in the years 1864-1865 after the end of Russian-Circassian war in favor of the Russian State in May 21, 1864. Peoples who were Circassians, Dagestanis, Nogai, Chechens, Karachai and Kumuklu from Caucasus were forced to migrate to the Ottoman Empire from 1850 to 1920 s $^{6}$.

Refugees from Caucasus to the Ottoman region, due to the Ottoman State Housing Policy, were housed in Anatolia and Rumelia banner close to the the Black Sea coast, Aegean and the Mediterranean ports, and Konya, Sivas and Baghdad where has land in large areas ${ }^{7}$. Meanwhile, the Circassians who want to emigrate were gradually adopted particularly by giving priority to relatives who had previously emigrated to Memalik-i Mahruse ${ }^{8}$. Besides, the instructions prepared to prevent congestion and irregularities occurring during the transmission of Circassian refugees were sent to the officers ${ }^{9}$.

\section{2) Settling}

As a result of information that we have identified in the documents of Prime Ministry Ottoman Archives, Circassian immigrants came to Rumelia in 1860 and later were resettled in sanjak and district as seen as follows: Edirne ${ }^{10}$, Tekfurdağ ${ }^{11}$, Plovdiv $^{12}$, İslimye ${ }^{13}$, and Gallipoli ${ }^{14}$ sanjaks, Ruse ${ }^{15}$, Varna ${ }^{16}$, Vidin ${ }^{17}$, Tulcea and Constanta $^{18}$, Veliko Tarnovo ${ }^{19}$, Svishtov, Silistra, Niğbolu sanjaks ${ }^{20}$, Sofia ${ }^{21}$ and

${ }^{5}$ İzzet Aydemir, Göç (Kuzey Kafkasyalıların Göç Tarihi), Gelişim Matbaası, Ankara 1988, s. 156-157.

6 Ömer Karataş, "19. Yüzyılda Balkanlarda..”, s. 357; Muzaffer Tepekaya, “19. Yüzyılın İkinci Yarısında Kırım ve Kafkasya'dan Göç Hareketleri ve Saruhan(Manisa) Sancağı'na Göçler", Türk Dünyası Incelemeleri Dergisi, c. VI, Sayı 2, s.470; A. Cevat Eren, Türkiye'de Göç ve Göçmen Meseleleri Tanzimat Devri Illk Kurulan Göçmen Komisyonu Çıkarılan Tüzükler, Nurgök Matbaas1, İstanbul 1996. s.64-66; Sedat Kanat, Same Tessis, s. 34.

7 Ömer Karataş, "19. Yüzyılda Balkanlarda...", s. 358; Ottoman Archives of the Prime Ministry of the Republic of Turkey(BOA), Amedî Kalemi Mektubi Mühimme Evrakı (A.MKT.MHM), no. 323/59; 318/39; Cevdet Dâhiliye (C.DH), no. 173/8610; 44/2157; BOA, Meclis-i Vâlâ Evrakı Zabıt Cerideleri Hülasaları (MVL), no. 1016/36; 714/12.

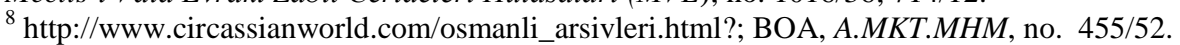

9: BOA, A.MKT.MHM, no. 324/23.

${ }^{10}$ BOA, $M V L$, no. $988 / 14$.

${ }^{11}$ BOA, A.MKT.MHM, no. $307 / 99$.

${ }^{12}$ BOA, $M V L$, no. $443 / 67$.

${ }^{13}$ BOA, C.DH, no. $163 / 8123$.

${ }^{14}$ BOA, A.MKT.MHM, no. 306/1.

${ }^{15}$ BOA, A.MKT.MHM, no. 301/40.

${ }^{16}$ BOA, A.MKT.MHM, no. 292/67.

${ }^{17}$ BOA, $M V L$, no. $982 / 6$

18 BOA, $M V L$, no. $969 / 14$.

${ }^{19}$ BOA, A.MKT.MHM, no. 323/41. 
Circassian Refugees: Future Residents of Rumelia / Yakup AHBAB

$\mathrm{Nis}^{22}$ sanjaks, Serres and Drama sanjaks ${ }^{23}$ in Thessaloniki State, Prizren ${ }^{24}$ sanjak, Dobrogea $^{25}$ sanjak in Bulgaria and were finally settled in Skopje ${ }^{26}$ sanjak. Caucasian immigrants sent to Rumeli were consisted of Crimea, Nogay and Circassians. 15.000 Circassians were sent to Niche and Kosovo to the settlement ${ }^{27}$.

Government dispathced the refugees to Rumelia and the Balkans according to objectives of housing policy because of reasons such as the vast land in Rumelia, wishes to be increasing the Muslim population in this region, and the need for troops in the extreme. Therefore, empty, large, wooded and fertile state land with declining population was intended to revitalize again as a result of the migration, strengthen of state authority around the land, and bring revenue to the treasury ${ }^{28}$. Within the framework of this policy being followed by the government, Circassian emigrants had tried to be inhabited to build for castle and fortification for maintaining the border region between Podgorica and İşbuz ${ }^{29}$.

The place where a Circassian refugee placed was in discretion of the government. Refugees did not need any special permission to go to another province; but people moved to another province were required to notify the authorities in order to ensure the continuity. In such cases, the authorities were helping the refugees. Only they had to satisfy the housing expenses themselves where they moved. There are examples associated with it as follows: six convoys of Circassian refugees fled from Pristina, where they were replaced before, because of

${ }^{20}$ BOA, A.MKT.MHM, no. 305/94.

${ }^{21}$ BOA, A.MKT.MHM, no. 328/15.

${ }^{22}$ BOA, $M V L$, no. $983 / 66$.

${ }^{23}$ BOA, $M V L$, no. $1018 / 73$.

${ }^{24}$ BOA, A.MKT.MHM, no. $314 / 100$.

${ }^{25}$ BOA, $M V L$, no. $969 / 13$.

${ }^{26}$ Kemal Karpat, Osmanlı'dan Günümüze Etnik Yapılanma ve Göçler, Timaş Yayınları, İstanbul 2010, s. 171

${ }^{27}$ Takvim-i Vekayi (T.V), no. 759-1, (28 Safer 1281); 1.500 households Circassian immigrants were sent to Prizren to be resettled: T.V, no. 764-2, (4 Rabiülahir 1281); Immigrant population directed to from the Caucasus to Rumelia is a controversial issue. In our work, we can give the results from the following information from documents and other sources of data that the data about population of refugees and regions resettled by Ottoman government in Rumelia until the end of 1861 as follows: 34.344 households and 142.852 population in the Danube Regions of Rumeli shores; 2.445 households and 10.289 population in Edirne Province; 768 households and 4421 population in Thessaloniki State: Ömer Karataş, ' 19. Yüzyılda Balkanlarda...', s. 363-365; Kemal Karpat, Osmanlı'dan Günümüze Etnik Yapılanma ve Göçler, s. 162-172; Bedri Habiçoğlu, Kafkasya'dan Anadolu'ya Göçler, Nart Yayınc1lık, İstanbul 1998, s. 159-162- 363; Kemal Karpat, "Avrupa Egemenliği'nde Müslümanların Konumu Çerkeslerin Sürgünü ve Suriye'deki İskânı”, Çerkeslerin Sürgünü, Kafder Yayınları, Ankara 2001, s. 78-111; Ömer Şen, "Osmanlı Devleti'nde Kafkas Göçmenleri Sorunu (1834-1870)”, Dünü ve Bugünüyle Toplum ve Ekonomi, Temmuz 1997, sa. 10 , s. $125-133$.

${ }^{28}$ Ömer Karataş, ‘'19. Yüzyılda Balkanlarda...’’, s. 358; BOA, MVL, no. 978/82.

${ }^{29}$ BOA,TŞ.BRNM,no.25/120;http://www.unhcr.org.tr/uploads/root/s\%C4\%B1k_sorulan_sorul ar.pdf? 
Circassian Refugees: Future Residents of Rumelia / Yakup AHBAB

going to near of their relatives and stopped in Palanka did not prevented by the security forces. Moreover the administrators were cautioned to show the effort to help them housing near the relatives when convoys arrived to Shumen ${ }^{30}$. Residential Circassian refugees who were requested the license from Pristina to Edirne transfer were permitted to leave the refugee donation they received and then replaced in Edirne where they had to pay housing costs themselves ${ }^{31}$. In 1879, it was requested to prevent the migrated Circassians return from Kosovo to Anatolia and Arabia. In addition, caution to all the troupe and agencies were required to be done in this way $^{32}$.

\section{3) Problems}

The refugees present in extremely difficult conditions should be needed to be fed, provided places to stay, land and labored by the government. There was literally an immigrant drama in Tekfurdağı. Circassian refugees here were waiting for to extend a helping hand to them in miserable ${ }^{33}$. The most striking point in the human tragedy was that some of the refugees did not even have a piece of clothing to wear. The most urgent three needs were determined to prevent such situations by the Government after the arrival of migrant Circassians to Rumelia. Identified three urgent needs were dwelling immigrants to settle in, food they consume daily, and tiller tool and industrial equipments required to ensure livelihood ${ }^{34}$. For the dwelling households issue in these urgent needs, required households were made by help of the population lived in most places of the province, but some households remained incomplete ${ }^{35}$. Because of a number of households of immigrants did not yet built, making the households of both newcomers as well as precomers immigrants who did not have a place to live in were considered to be completed expeditiously since $\mathrm{March}^{36}$. Not leaving the immigrants outside was the main objective of this idea. The solution to the households problem of immigrates were left to the efforts of all civil servants, try and help of the generous Ottoman people ${ }^{37}$. Firstly, one hundred sixteen houses were built for refugees sent to Skopje. 59.200 bucks of costs of these household were also borne by the

${ }^{30}$ BOA, $M V L$, no. $1023 / 29$.

${ }^{31} \mathrm{BOE}, M V L$, no. 1019/14; Another example is demanding the return of Circassian immigrants gone from Skopje to Pazardzhik in 1867: BOA, A.MKT.MHM, no. 383/86.

32 BOE, A.MKT.MHM, no. 484/25; Twenty-five households refugees were tried for resettlement at the farm Keşkinli near Edirne because of dislike the Visa posted on to be settled: BOE, $M V L$, no. $1021 / 28$.

${ }^{33}$ BOA, $M V L$, no. $1005 / 75$.

${ }^{34}$ Immigrants from those not yet been settled were given wages and bread rations new arrivals: BOA, A.MKT.MHM, no. 323/84.

35 Donation money treasury would be able to help the Circassian refugees: BOA, A.MKT.MHM, no. 325/83.

36 Ömer Karataş, ''19.Yüzyılda Balkanlarda...', s. 369; Circassian refugees resettled İştib district was conducted in support of flour: BOA, C.DH, no. 192/9586.

37 BOA, A.MKT.MHM, no. 314/100. 
Circassian Refugees: Future Residents of Rumelia / Yakup AHBAB

population ${ }^{38}$. They tried generally to fill the gap of resulted services and benefits with volunteer help. Rumeli people who could not see any financial assistance from the government helped refugees at their own ${ }^{39}$. For example, campaign was organized in Skopje to help refugees in the year 1865 and collected aid was sent to the treasury. Financial resources enabling for relief activities was provided by donations collected from local business community, the people and officers ${ }^{40}$.

One of the most important problems of refugees was food and nutrition. Starting from children, malnutrition was a major problem. They were trying to feed themselves by getting help. Meanwhile, the question "Is there a special health policy of the state for asylum seekers?" comes to our mind. State were tried to allocate resources for refugees. Despite this, Circassian refugees lived in conditions such as housing, education, health, in many aspects, contrary to human rights. Refugees had to be provided their priority needs such as health and housing conditions by the control of State, in accordance with the human rights. Because of the reasons such as physical lack of living conditions, the weakness of the hygiene conditions and lack of medical services, emergence of many types of diseases in refugee was inevitable. It was necessary to carry out an accurate health projects to prevent the formation of these diseases and their transmissions by the government. Therefore emigrants who were patients were treated ${ }^{41}$. In addition, the steps were taken for refugees from those who did not yet smallpox to get vaccination ${ }^{42}$. In addition to these precautions, immigrant patients were sent to Gallipoli to receive the treatment ${ }^{43}$. It was decided to leave the remaining amount of the incurred costs to treasury after the settlement Circassian emigrants in Sofia and to build a military hospital with this amount ${ }^{44}$. As can be seen, access to a very important service such as health care is providing an extremely valuable contribution.

Circassian refugees living in the city had to work for their survivals. Immigrants came to Rumelia were provided housing and business facilities under policies implemented by state. Because of the vast majority of receivers were farmers, it increased the importance of the production style and the climate where they came from in terms of adapting to the settlement to be made in rural areas. For providing job opportunities for immigrants and the improvement of working conditions, in kind and cash benefits were made, in this context, family

\footnotetext{
${ }^{38} T . V$, no. 809-2, (27 Safer 1282).

39 http://www.igamder.org/wp-content/uploads/2012/06/Suriye-STK-Raporu.pdf; The money collected by the inhabitants and officers of Skopje in 1860 was sent to where it was necessary per post: BOA, A.MKT.MHM, no. 189/21;237/30;232/42.

${ }^{40}$ BOA, A.MKT.MHM, no 338/1.

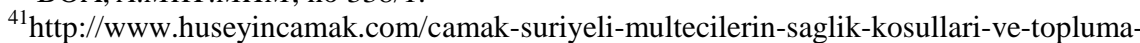

etkilerini-sordu.html; BOA, A.MKT.MHM, no.236/59.

${ }^{42}$ BOA, A.MKT.MHM, no. 304/51.

${ }^{43}$ BOA, A.MKT.MHM, no. 306/1.

${ }^{44}$ BOA, A.MKT.MHM, no. 328/15.
} 
Circassian Refugees: Future Residents of Rumelia / Yakup AHBAB

farmers were given agricultural land and $\operatorname{seed}^{45}$. Circassian refugees settled in Rumeli and given deeded land had the right to sell or to give lease the land that gain their own money and they left behind them in response to obtained the same amount of land when they moved to Anatolia ${ }^{46}$.

Wages paid to emigrant is given by the treasure and Ottoman inhabitants, but these wages given constantly leaved long-standing difficulties for both sides. To put an end to this situation, the precautions were taken in Rumeli side. As for the precautions taken in the first, needy immigrants were given lands to make agriculture in some places given in the example as one in Skopje ${ }^{47}$. But winter season without precipitation caused to drought, frost disaster due to extreme heat or damaged in agricultural products in Rumelia from time to time and refugees were also affected by this situation. In case of such negative experiences, aid to refugees by the government taking the necessary precautions and support were made. For example, residential Circassian refugees in districts Gnjilane, Pristina, and Vulçıtr who could not get the poor crop because of drought were given half wages and while those who lost their ox because of disease were given ox in condition that the costs to be paid in installments ${ }^{48}$.

The Circassian refugees lived the war and forced to migrate were struggling for survival under difficult conditions in Rumeli. Refugees settled in the home made by them were struggling and lived in difficulties here. Citizens helped as well as they could without remaining silent misery experienced by refugees, but it was not seen as a permanent solution for pruning. Especially population was known not to get along with the refugees because of the language difference and had difficulties to find solutions to their problems. Upon this, it was on the agenda to give an interpreter in order to deal better with the local population and refugees. In this context, Ibrahim Efendi was appointed as translator of Circassian refugees placed in the Thessaloniki State with two hundred and fifty bucks salary ${ }^{49}$.

The migrants settled in the Rumeli side dispatched by the government just came by not only moving their bodies, but also with their culture and social life. A regular military system was not a subject because there was not a state formation belongs to Caucasian peoples living in the Caucasus. Circassian tribes living in the Caucasus had a feudal structure. Therefore, anyone holding a weapon in case of any danger came together to fight against the common enemy and the danger was

\footnotetext{
${ }^{45}$ http://etatar.blogspot.com.tr/; The given amount of subsidized bread for their households rent of Circassian emigrants being placed İslimye, Aydos district and arounds were given five clay of seed rations per home: BOA, C.DH, no. 163/8123; Examples can be increased. For example, the Circassian refugees aided by population of the Big and Gallipoli with wheat seed for cultivation: BOA, A.MKT.MHM, no. 324/83.

${ }^{46}$ BOA, Irade Şura-yı Devlet( I.ŞD), no. 49/2745.

${ }^{47}$ Ömer Karataş, "'19. Yüzyllda Balkanlarda...", s. 369; Tercüman-ı Ahval, no. 91/1-2, (9 Rebiülahir 1278).

${ }^{48}$ BOA, $M V L$, no. 1023/10; 1067/126; 983/24; 983/66.

${ }^{49}$ BOA, $M V L$, no. 1018/73; http://www.malatyasurmanset.com.tr/gundem/vali-bey-neredesinh2263.html?
} 
Circassian Refugees: Future Residents of Rumelia / Yakup AHBAB

finished, they returned to their habitat. That was why the peoples of the Caucasus were using all weapons. The use of the weapon and possession in the Ottoman Empire had just released for soldiers. Therefore Ottoman population consisting of Muslim and non-Muslim subjects still maintained as living unarmed. When Nogay, Crimea and Circassian immigrants was emerged and resettlement in Rumelia, the use of weapons began to be problem. The use of arms by immigrants in some cases led to conflicts with population ${ }^{50}$.

The Ottoman Empire was always hospitable and welcoming towards refugees. However, the number of Circassians came to Rumelia with the war taking place in the Caucasus were increasing with each passing day. Public order disrupted with the arrival of the refugees; an increase was seen in the incident of theft and extortion., murder incidents involving refugees and the Circassians in Rumelia revealed this situation clearly ${ }^{51}$. As a result of disturbing the inhabitants by migrants, the people complained to local authorities owing to the attitude of the immigrant population $^{52}$. Ottoman rule took some precautions as a result of an increase in complaints about this. One of these precautions was also sent to the orders on the movement of refugees in the province. An example in the history of 1862 is as follows: It was ordered by grand vizier to the states to investigate the rumors that some Crimea, Nogai and Circassian refugees, who had emigrated to the Ottoman Empire, behaved not well to Christian people in places they were sent to and the precautions was need to be taken.

The response from the State of Skopje 'bu havâlide bulunan muhâcirîn asla o misillü harekât-ı nâ-marziyyede bulundukları mesbûk olmayıp mantûk-ı âlîsi vechile yine icra-yl tenbihât ve takayyüdâtda tecviz-i kusûr olunmayacağl derkâr bulunmus olmağla...' was specified ${ }^{53}$. It means that there was no certainity that the refugees behaved inappropriately, but the officers indicated that the required precautions would be taken excellently.

Ottoman Empire received all Circassians refuged to equal citizenship by the asylum status and accepted the case. But we understand from the cases regarding about slaves reflected by Ottoman authorities that the equation of state was not accepted by Circassian slave owners. For example, the slaves bought and sold in the region that Circassian were sent and lived ${ }^{54}$.

Some slaves were claiming freedom. The cases of freeing and hostage freed slaves and concubines came to court canonical ${ }^{55}$. Thus a lot of court slaveryrelated lawsuits came to the court, local administrators were asked to help from Emigrants Commission how to treat against towards on this situation. Emigrants Commission reflected subject to get the government assistance to meet the demands

\footnotetext{
${ }^{50}$ Ömer karataş, '19.Yüzy1lda Balkanlarda...’, s. 375; BOA, $M V L$, no. 1076/18; 1076/67.

${ }^{51}$ BOA, $M V L$, no. $1029 / 41 ; 1078 / 48 ; 1077 / 31$.

52 Ömer karataş, ‘'19.Yüzyılda Balkanlarda...’’, s. 375; BOA, $M V L$, no. 1029/30.

${ }^{53}$ BOA, Sadâret Mektubî Kalemi Umum Vilâyât (A.MKT.UM), no. 534/48.

${ }^{54}$ BOA, $M V L$, no. 991/39.

${ }^{55}$ BOA, $M V L$, no. $499 / 12$.
} 
Circassian Refugees: Future Residents of Rumelia / Yakup AHBAB

of the local executives. Then the government, by considering the situation regarding the Circassian slave, had made regulations on how to treat the slaves and owners. New legislation on slavery by the Government wrote to all local officials where the Circassian immigrants were placed in the Ottoman Empire. The government allowed sales of Circassians concubines and slaves only up to the 25-30 age (refugees who told and not hide about their slavery). It had been requested from the local officials not to involve this purchase and sale of slaves in this condition. The government identified the attitude taken clearly with sending the Imperial Decree including those decisions taken by the officers in places where the emigrants lived. The decree was sent to Rumelia places like Skopje ${ }^{56}$.

\section{RESULTS}

After the Crimean War in 1853-1856, the Ottoman state was confronted with an intense migration of the Circassians. This migration that experienced the most intense period in especially 1864 led to the Ottoman state in an intensive study in particular for the settlement of immigrants. While the government tried not only to identify regions of the refugees will be resettled, but also prepared for their places to reside temporarily. During this settlement activities, the government tried to open state lands inhabited empty for the refugees to comfort and for the local population not to be victims. In this case, the government had to deal with problems like the construction of houses the refugees would shelter in the empty land, field necessary in order to sustain their lives, the supply of equipment required for cultivation of these fields. In addition, disapproved inhabited immigrants resided in the land and wanting to go to their relatives who were settled in the Ottomans earlier were among the issues that Ottoman Empire had to deal with ${ }^{57}$.

\section{BIBLIOGRAPHY}

Ottoman Archives of the Prime Ministry of the Republic of Turkey

Amedî Kalemi Mektubi Mühimme Evrakı, Cevdet Dâhiliye, Meclis-i Vâlâ Evrakı Zabıt Cerideleri Hülasaları, Irade Şura-yı Devlet, Sadâret Mektubî Kalemi Umum Vilâyât

\section{Internet Source}

http://www.unhcr.org.tr/uploads/root/s\%C4\%B1k_sorulan_sorular.pdf.

http://www.igamder.org/wp-content/uploads/2012/06/Suriye-STK-Raporu.pdf.

http://www.huseyincamak.com/camak-suriyeli-multecilerin-saglik-kosullari-vetopluma-etkilerini-sordu.html.

http://etatar.blogspot.com.tr/

http://www.circassianworld.com/osmanli_arsivleri.html?

Books and Article

Aydemir, İzzet, Göç (Kuzey Kafkasyalıların Göç Tarihi), Gelişim Matbaası, Ankara 1988.

${ }^{56}$ Ömer Karataş, '19. Yüzyılda Balkanlarda', s. 379-380.

${ }^{57}$ Galip Çağ, '’19. Yüzyılda Çerkes Ve Nogay Göçmenleri N Anadolu'da İskânı Ve Çankırı Örneği,', Çankırı Karatekin Üniversitesi Ktisadi Ve İdari Bilimlerfakültesi Dergisi,Y.2013, Cilt 3, Say1 2, s.132-142. 
Circassian Refugees: Future Residents of Rumelia / Yakup AHBAB

Baddeley, John F.,Rusların Kafkasya'yı İstilası ve Seyh Şamil, (Çev. Sedat Özden), Kayıhan Yayınları, İstanbul 1989.

Berber, Ferhat, "Kırımlı ve Kafkasyalı Muhacirlerin Manisa Kazasında İskânı (1860-1876) ", Sosyal Bilimler Dergisi, Cilt:11, Sayı:3, Aralık 2013 Manisa Özel Sayıs1, s. 169-192.

Çağ, Galip, '19. Yüzyılda Çerkes Ve Nogay Göçmenleri N Anadolu'da İskânı Ve Çankırı Örneği'", Çankırı Karatekin Üniversitesi Ktisadi Ve İdari Bilimlerfakültesi Dergisi,Y.2013, Cilt 3, Sayı 2, Ss.132-142.

Demirtaş, Mehmet, 'Kırım Savaşı Ve 93 Harbi Sürecinde Osmanlı Memleketine Gelen Göçmenlerin Sevk Ve İskanları', A.Ü.Türkiyat Araştırmaları Enstitüsü Dergisi Say1 41 Erzurum 2009, S. 215-238.

Eren, A. Cevat, Türkiye'de Göç ve Göçmen Meseleleri Tanzimat Devri İlk Kurulan Göçmen Komisyonu Çıkarllan Tüzükler, Nurgök Matbaası, İstanbul 1996.

Erkan, Süleyman, Kırım ve Kafkasya Göçleri (1878-1908), KTÜ Yayını, Trabzon 1996.

Fonvill, A, Çerkesya Bağımsızlık Savaşı (1863-1864), (Çev. Murat Papsu), Nart Yayınc1lık, İstanbul 1996.

Habiçoğlu, Bedri, Kafkasya'dan Anadolu'ya Göçler, Nart Yayıncılık, İstanbul 1998. İpek, Nedim, Rumeli'den Anadolu'ya Türk Göçleri, TTK, Ankara 1994.

, "Kosova Vilayeti Dahilinde GerçekleşEn Göçler", History Studies, Vol 2, 1 / 2010, S. 65-81.

Kanat, Sedat, Osmanlı Devleti’ne Yapılan 1864 Kafkas Göçü, Atatürk Üniversitesi Sosyal Bilimler Enstitüsü, Yüksek Lisans Tezi, Erzurum 2011.

Karataş, Ömer '’19. Yüzyılda Balkanlarda Kafkas Muhacirlerinin İskanı', Türk Dünyası Incelemeleri Dergisi, XII/2 (Kış 2012), S. 355-388.

Karpat, Kemal, Osmanlı'dan Günümüze Etnik Yapılanma ve Göçler, Timaş Yayınları, İstanbul 2010.

“Avrupa Egemenliği'nde Müslümanların Konumu Çerkeslerin Sürgünü ve Suriye'deki İskânı”, Çerkeslerin Sürgünü, Kafder Yayınları, Ankara 2001.

Şen, Ömer, “Osmanlı Devleti’nde Kafkas Göçmenleri Sorunu (1834-1870)”, Dünü ve Bugünüyle Toplum ve Ekonomi, Temmuz 1997, sa. 10, s. 125-133.

Satış, İhsan, 'Kırım Savaşından Sonra Kafkasya'dan Anadolu'ya Göçler Ve Şanlıurfa Yöresine İskanı', Türk Dünyası İncelemeleri Dergisi / Journal Of Turkish World Studies, XII/1 (Yaz 2012), . 517-531.

Şen, Ömer, “Osmanlı Devleti'nde Kafkas Göçmenleri Sorunu (1834-1870)”, Dünü ve Bugünüyle Toplum ve Ekonomi, Temmuz 1997, sa. 10, s. 125-133.

Tepekaya, Muzaffer , “19. Yüzyılın İkinci Yarısında Kırım ve Kafkasya'dan Göç Hareketleri ve Saruhan(Manisa) Sancağı'na Göçler”, Türk Dünyası Incelemeleri Dergisi, c. VI, Sayı 2, s.463-480.

Pul, Ayşe, ' '1877-78 Osmanl1-Rus Savaşı Sonrası Beykoz'da Muhacirler İÇin İSkân Yeri ÇalışMaları', Tarih Okulu Dergisi (TOD) Eylül 2013Yıl 6, Sayı XV, Ss. 159-182. 